\title{
UPAYA PELESTARIAN KESENIAN KHAS \\ DESA MEKARSARI DAN DESA SIMPANG, KECAMATAN CIKAJANG, KABUPATEN GARUT
}

Soemantri, S. Ypsi., Indira, D. dan Indrayani, L.M.

Staf Pengajar Fakultas Ilmu Buidaya Universitas Padjadjaran

E-mail: ypsi.soerias@gmail.com; diancpds@yahoo.com; lia.maulia.i@gmail.com

\begin{abstract}
ABSTRAK
Kesenian khas daerah Sunda merupakan salah satu kekayaan budaya yang ada di Jawa Barat. Dengan adanya globalisasi, kebudayaan dan kesenian Sunda sedikit demi sedikit mengalami pergeseran, Kepunahan suatu kesenian lokal sebagai aset budaya daerah dapat terjadi apabila dalam masyarakatnya terutama generasi muda kurang peduli dan tidak memiliki keinginan untuk meneruskan dan mengembangkan serta melestarikan keberadaan seni tradisional tersebut. Berdasarkan kondisi tersebut, perlu dilakukan upayaupaya supaya kesenian khas dapat dipertahankan eksistensi dan kelestariannya sebagai aset budaya lokal setempat. Oleh karena itu, melalui kegiatan Pengabdian Kepada Masyarakat Integratif ini, kami melakukan inventarisasi kesenian khas apa saja yang ada di Desa Mekarsari dan Desa Simpang Kecamatan Cikajang, Kabupaten Garut dan upaya-upaya apa saja yang sudah dan perlu dilakukan agar seni dan budaya yang ada tidak punah atau tergeser oleh budaya barat. Dengan dilaksanakannya PKM-Integratif "Upaya Pelestarian Kesenian Khas Di Desa Mekarsari dan Desa Simpang Kecamatan Cikajang, Kabupaten Garut" diharapkan dapat memotivasi generasi muda setempat untuk dapat lebih menghargai dan mencintai kesenian khas daerahnya sebagai warisan budaya Sunda yang harus dijaga dan dilestarikan.
\end{abstract}

Kata kunci: kesenian khas, aset budaya, Sunda, pelestarian

\section{ABSTRACT}

The typical Sundanese art is one of the cultural richness in West-Java Province. But globalization brings effect to the Sundanese culture and art that has gradually shifted. The extinction of local art as indigenous cultural heritage will probably exist if the communities particularly young generation, pay less attention and have no awareness to maintain, promote and preserve the existence of their local tradition. Regarding this condition, efforts to safeguard and protect indigenous cultural heritage should be made. Therefore, by conducting this activity (PKM-Integratif), we make the documentation of what typical indigenous tradition belongs to local people in Desa Mekarsari and Desa Simpang Kecamatan Cikajang, Kabupaten Garut, what efforts have been made and what actions should be taken to maintain and preserve the existing culture and art from extinction or replaced by western culture. By performing "The Cultural Heritage Preservation Efforts in Desa Mekarsari dan Desa Simpang Kecamatan Cikajang, Kabupaten Garut", this could motivate local young generation to give more respect and love to their own cultural heritage as Sundanese cultural legacy that needs to be maintained and preserved.

Key word: arts, cultural asset, Sundanese, preservation

\section{PENDAHULUAN}

Kesenian berasal dari kata 'seni', yang memiliki arti indah dan segala sikap dan perilaku manusia yang memiliki sifat indah dan dapat memengaruhi jiwa manusia lainnya disebut dengan kesenian. Berdasarkan pengertian kesenian sebagai perbuatan manusia yang mengekspresikan perasaan keindahan, maka kesenian khas satu daerah dikatakan merupakan jati diri daerah tersebut. Dengan kesenian khas itulah, satu daerah dapt dibedakan dengan daerah lainnya.

Dengan berjalannya waktu eksistensi kesenian khas daerah Desa Mekarsari dan Desa Simpang, kecamatan Cikajang menuju kepunahan. Hal ini dapat diasumsikan demikian karena kesenian ini sudah tergeser oleh kesenian lain dari luar daerah kabupaten Garut dan hanya sebagian kecil masyarakat desa yang masih memainkannya. Untuk itu, dalam pelaksanaan pengabdian kepada masyarakat (PKM) yang dilaksanakan di Desa Mekarsari dan Desa Simpang, Kecamatan Cikajang, Kabupaten Garut, akan difokuskan pada upaya pelestarian kesenian di kedua desa tersebut. Di desa-desa ini kesenian yang menonjol adalah seni tari dan seni tarik suara sehingga dua bentuk kesenian ini yang menjadi objek pelaksanaan kegiatan PKM.

Desa Mekarsari dan Desa Simpang terletak di kaki Gunung Papandayan. Ke dua desa tersebut memiliki pemandangan yang sangat indah. Desa Mekarsari dikelilingi oleh perkebunan teh di sisi kirinya dan perkebunan sayur-mayur di sisi kanannya, sedangkan Desa Simpang di kelilingi oleh kebun sayur-sayuran seperti buah tomat, kentang, sawi, kol dan lain-lain.

Desa Mekarsari merupakan pemekaran dari Desa Cikajang di Kecamatan Cikajang. Luas desa Mekarsari adaalah 210 Ha memiliki 3 dusun, 9 RW dan 34 RT. Jarak dari Kota Garut ke Desa Mekarsari sejauh 25 km. Jumlah penduduk Desa Mekarsari adalah 5.678 orang laki-laki dan 2.814 orang perempuan dengan jumlah kepala keluarga sebanyak 1630 orang.

Penduduk Desa Mekarsari kebanyakan bekerja sebagai buruh tani yaitu sebanyak 1570 orang, petani sebanyak 567 orang. Sisanya memiliki pekerjaan yang bervariasi seperti PNS 21 orang, TNI 8 orang, dan Polri 1 orang. Desa Mekarsari memiliki beberapa kesenian khas yang masih hidup di masyarakat, seperti calung, jaipongan, degung, dan debus. Desa Mekarsari memiliki beberapa perguruan pencak silat seperti Cempaka Warna dan Putra Pustaka Sridarma Mekar.

Lain halnya dengan Desa Simpang yang terletak $3 \mathrm{~km}$ ke arah Timur dari Desa Mekarsari, Desa Simpang juga merupakan pemekaran dari Desa Cikajang. Desa Simpang memiliki letak geografis pegunungan dan perbukitan dengan suhu rat-rata 18$21^{\lrcorner}$C. Letak Desa Simpang kira-kira $32 \mathrm{~km}$ dari Kota 
Garut. Mata pencaharian masyarakat Desa Simpang sangat bervariasi, kebanyakan penduduk Desa Simpang berprofesi sebagai buruh yaitu sebanyak 878 orang, petani penggarap sebanyak 260 orang dan petani pemilik sebanyak 284 orang. Sisanya berfprofesi sebagai PNS 20 orang, militer 7 orang, pegawai BUMN 3 orang, dan wirausaha 88 orang. Perkembangan dalam bidang pendidikan di desa Simpang masih sangat minim karena masih ditemukannya anak yang tidak tamat sekolah dasar dan hanya sedikit yang tamat sekolah menengah atas. Kesenian di Desa Simpang, selain bentuk-bentuk kesenian yang ada di Desa Mekarsari seperti calung, jaipongan dan ibing pencak, terdapat pula kesenian yang dipengaruhi agama Islam yaitu qasidah dan marawis.

Mengingat kemajuan teknologi, khususnya penemuan-penemuan di bidang teknologi komunikasi, dan masih adanya masyarakat yang menjadikan negara Barat sebagai kiblat pusat mordernisasi, memungkinkan budaya atau seni barat masuk dan dinikmati seluruh lapisan masyarakat. Hal ini berpengaruh tidak saja pada gaya hidup tetapi juga kesenian daerah. Bukan tidak mungkin pengaruh seni barat tersebut akan menggerus kesenian khas di Desa Mekarsari dan Desa Simpang dan harus ada upaya-upaya melestarikannya. Dalam kegiatan PKM tersebut dikaji kesenian khas apa saja dan upayaupaya apakah yang sudah dan perlu dilakukan di kedua desa itu untuk melestarikan kesenian yang sudah ada.

\section{SUMBER INSPIRASI}

Kesenian khas di Kecamatan Cikajang, Kabupaten Garut sangat beragam, meskipun letak antara satu desa dengan desa yang lainnya berdekatan, namun kesenian khas dari satu desa berbeda dengan kesenian khas desa lainnya. Demikian pula halnya dengan Desa Mekarsari dan Desa Simpang, meskipun kedua desa tersebut berada di Kabupaten Garut, namun kesenian tradisional di kedua desa tersebut memiliki kekhasannya sendiri. Seni tari jaipongan, degung, dan pencak silat masih hidup dan berkembang di masyarakat Desa Mekarsari, sedangkan seni yang masih dipentaskan dalam acara-acara tertentu di Desa Simpang adalah seni calung, jaipongan, ibing pencak, qasidah, dan marawis. Dengan demikian, di masingmasing desa di samping adanya jenis kesenian yang sama, masing-masing daerah pun memiliki kesenian yang menonjol di daerahnya, untuk seni qasidah dan marawis telah dikenal oleh masyarakat umum sebagai seni yang menonjol di Desa Simpang. . Berikut ini penjelasan tentang jenis-jenis kesenian yang ada di kecamatan Cikajang

\section{a. Pencak Silat}

Pencak Silat berkembang dengan baik, terdapat beberapa anggota masyarakat desa yang masih mengajarkan pencak silat kepada generasi muda desa. Mereka tidak memiliki padepokan, tetapi mereka berlatih di pekarangan rumah dengan diiringi kendang pencak. Jurus-jurus dasar Ibing Pencak biasanya diajarkan di sekolah dasar di daerah ini. Pencak silat adalah kegiatan bela diri yang merupakan bela diri yang menjadi ciri khas di daerah ini.. Selain untuk bela diri, umumnya di daerah Sundat, pencak silat dapat juga dijadikan sebagai sumber keindahan bentuk, gerak, irama dan ekspresi yang melukiskan adegan serang bela dengan menggunakan tangan kosong maupun senjata yang disebut dengan ibing pencak.

\section{b. Tari Jaipongan}

Jaipongan adalah seni tari yang lahir dari kreativitas seorang seniman asal Bandung, Gugum Gumbira. Ia terinspirasi pada kesenian rakyat yang salah satunya adalah Ketuk Tilu menjadikannya mengetahui dan mengenal betul perbendaharan pola-pola gerak tari tradisi yang ada pada Kliningan atau Bajidoran atau Ketuk Tilu. Karya Jaipongan pertama yang mulai dikenal oleh masyarakat adalah tari "Daun Pulus Keser Bojong" dan "Rendeng Bojong" yang keduanya merupakan jenis tari putri dan tari pasangan (putra dan putri). Awal kemunculan tarian tersebut semula dianggap sebagai gerakan yang erotis dan vulgar, namun semakin lama tari ini semakin popular dan mulai meningkat frekuensi pertunjukkannya, baik di media televisi, hajatan, maupun perayaan-perayaan yang disenggelarakan oleh pemerintah atau oleh pihak swasta.

\section{c. Calung}

Calung adalah alat musik dari bamboo tetapi cara memainkan calung berbeda dengan angklung yang dimainkan dengan cara ditabuh yaitu dengan memukul batang (wilahan, bilah) dari ruas-ruas (tabung bambu) yang tersusun menurut titi laras (tangga nada) pentatonik (da-mi-na-ti-la). Jenis bambu untuk pembuatan calung kebanyakan dari awi wulung (bambu hitam), namun ada pula yang dibuat dari awi temen (bambu yang berwarna putih). Di samping pengertian calung selain sebagai alat musik, pengertian calung juga melekat dengan sebutan seni pertunjukan. Ada dua bentuk calung Sunda yang dikenal, yakni calung rantay dan calung jinjing.

Jenis kesenian yang telah disebutkan di atas perlu diupayakan agar tetap hidup di masyarakat sebagai kekhasan yang dimiliki masyarakat di kedua desa tersebut, karena di daerah Garut sendiri beberapa kesenian khas daerah ini nyaris punah. Misalnya sejak lama 'adu domba' merupakan kesenian yang sangat terkenal di daerah Garut, namun eksistensinya sudah tidak seperti dahulu. Hal ini berkaitan dengan kuatnya nilai keislaman masyarakat di daerah Kabupaten Garut, karena beberapa dari mereka menganggap bahwa adu domba berkaitan dengan masalah judi yang dilarang oleh agama. Adu domba dimasukan ke dalam kategori kesenian, karena dalam kegiatan adu domba terdapat tari-tarian tradisional yang dilakukan oleh pemilik domba dan wasit. Tari-tarian ini diiringi oleh kendang pencak, terompet dan gong.

Adu domba merupakan ajang pamer ketangkasan hewan ternak yang pada akhirnya akan menaikan gengsi suatu perkumpulan ternak hewan. Dalam adu domba terdapat satu orang wasit dan satu orang penilai. Biasanya setiap pertandingan dibagi dalam dua ronde dan masing-masing ronde terdiri dari 10 kali tumbukan kepala domba. Adu domba ini diiringi pula oleh musik tradisional. Sebelum acara lomba berlangsung, wasit dan pemilik domba akan menari jaipongan dahulu. 
Saat ini di Kabupaten Garut sendiri tercatat beberapa kesenian yang sudah punah, di antaranya:

\section{a. Kesenian Lais}

Kesenian ini diambil dari nama seorang yang sangat terampil memanjat pohon

Memanjat pohon kelapa, ia Bernama Laisan dan sehari-harinya dipanggil pak Lais. Pak Lais sudah dikenal sejak jaman Belanda, tepatnya di kampung Nangka Pait, Kecamatan Sukawening, kabupaten Garut. Kemudian lais dikenal sebagai kesenian akrobat tradisional, yang penari utamanya bergelantungan menari berputar-putar tanpa pengaman pada seutas tali rami yang diikatkan pada 2 batang bambu. Penari bergelantugan sambil diiringi oleh musik pencak silat dan dibumbui oleh cerita dan adegan jenaka yang dibawakan oleh penari lainnya. (Sumber Situs Pemkab Garut)

\section{b. Kesenian Reog}

Kesenian reog Sunda terdiri dari dari 4 pemain yang masing-masing memainlan dog-dog atau gendang Sunda dalam ukuran yang berbeda-beda. Dua dari empat pemain berperan sebagai dalang dan wakil dalang, sementara dua lainnya sebagai pembantu dalang. Para pemain reog selain bernyanyi, mereka pun berguyon yang isinya berupa kritik fenomena sosial. (Sumber Situs Pemkab Garut)

\section{c. Kesenian Debus Garut}

Kesenian Debus Garut hampir sama dengan kesenain Debus Banten. Para pemain mempertontonkan kekebalan tubuhnya bila ditusuk-tusuk dengan benda tajam. Debus dalam bahasa Arab yang berarti senjata tajam yang terbuat dari besi dan mempunyai ujung yang runcing dan berbentuk sedikit bundar. Dengan alat inilah para pemain debus dilukai, dan biasanya anggota tubuh pemain tidak dapat ditembus walaupun debus itu dipukul berkali kali oleh orang lain. Atraksi ini biasanya berada di daerah pesisir seperti di daerah Pameungpeuk, namun di desa Mekarsari kesenian ini masih dipentaskan secara berkala (Situs Pemkab Garut).

\section{METODE PELAKSANAAN KEGIATAN}

Metode yang dilakukan dalam kegiatan PKM ini adalah observasi untuk mengetahui kesenian tradisional apa saja yang masih berkembang, baik di Desa Mekarsari maupun di Desa Simpang. Setelah melakukan pemetaan diputuskan para mahasiswa UNPAD yang sedang mengikuti program KKNM untuk ikut berpartisipasi dalam kegiatan atau latihan yang dilakukan. Hal ini dimaksudkan agar para peserta KKNM dapat mengetahui tingkat kesulitan mempelajari kesenian tradisional.

Di samping metode partisipasi, dilakukan juga metode diskusi, baik dengan aparat desa/ tokoh masyakat, pelaku seni, maupun masyarakat umum. Untuk memperoleh data yang akurat, dalam penelitian ini disebarkan kuesioner sehingga dapat diperoleh masukan bagaimana pelaku kesenian dapat terlibat di dalam aktivitas kesenian. Aparat desa, tokoh masyarakat, serta pelaku seni sebagai nara sumber patut diambil sebagai nara sumber karena mereka mengenal dan mengetahui kebudayaan setempat. Selain itu, baik aparat desa, tokoh masyarakat, maupun pelaku seni dapat melihat bahwa para mahasiswa Unpad peserta KKNM ternyata memiliki kehirauan terhadap kesenian daerah, sehingga diharapkan interaksi yang terjadi akan mendorong yang bersangkutan untuk terus mendorong berkembangnya kesenian di kedua desa tersebut.

Pelatihan pencak silat di Desa Mekarsari dilakukan di Balai Desa. Bapak Maman, seorang pelaku kesenian di Kecamatan Cikajang, membawa kerabatnya seorang pelatih pencak silat dan istrinya seorang penari Jaipongan. Setiap minggu para mahasiswa dan para remaja desa berlatih pencak silat dan Tari Jaipongan.

Begitu pula di Desa Simpang, para mahasiswa dan para remaja berlatih pencak silat di pekarangan rumah seorang pelatih pencak silat, mereka berlatih dengan diiringi kendang pencak. Mahasiswi KKNM berlatih menari Jaipongan di rumah seoranga anggota masyarakat yang mampu menari Jaipongan. Sesaat sebelum kegiatan KKNM berakhir dilaksanakan pagelaran kesenian di Desa Mekarsari yaitu di halaman Sekolah Dasar dan juga di Gedung Serba Guna Desa Simpang.

\section{TUJUAN}

1. Melakukan pemetaan kesenian khas yang manakah yang masih ada dan masih dipertunjukkan di Desa Mekarsari dan Desa Simpang, Kecamatan Cikajang Kabupaten Garut?

2. Mencari solusi bagaimana menumbuhkan motivasi generasi muda untuk melestarikan kesenian khas di Desa Mekarsari dan Desa Simpang, Kecamatan Cikajang Kabupaten Garut agar kesenian khas daerah di kedua desa tersebut tidak punah atau tergeser oleh kesenian global yang modern?

Melalui kegiatan yang dilakukan diharapkan dapat menumbuhkan kembali rasa cinta pada kesenian tradisional khas daerah mereka sendiri, menumbuhkan sikap masyarakat desa untuk menghargai kesenian khas daerahnya sendiri, memupuk keinginan masyarakat desa untuk melestarika kesenian daerahnya sendiri, dan mendorong potensi masyarakat desa dalam berkesenian khas daerahnya sendiri.

\section{KARYA UTAMA}

Upaya melestarikan kesenian dapat dilakukan dalam beberapa cara:

a. mengajarkan kesenian khas kepada generasi muda daerahnya (mengajarkan secara turun temurun,

b. mendokumentasikannya secara detail untuk disampaikan kepada generasi mendatang,

c. mempertunjukkan kesenian tersebut secara berkala di daerahnya,

d. diajarkan sejak usia dini yaitu para murid sekolah dasar atau sekolah menengah diwajibkan untuk mempelajari kesenian tersebut di sekolah,

e. mempopulerkannya keluar daerahnya, baik secara nasional maupun internasional,

f. mengadakan kompetisi kesenian tersebut sehingga masyarakat termotivasi berlomba-lomba untuk memenangkannya,

g. menumbuhkan kecintaan masyarakat pada kesenian sendiri dan merasa bangga memiliki kesenian tersebut. 
Masyarakat yang hidup dalam kelompok tertentu mempunyai kebudayaan yang khas, yang kekhasannya tersebut berbeda dengan kebudayaan kelompok masyarakat lainnya. Unsur-unsur yang dimiliki oleh semua kebudayaan dengan masyarakat yang berlainan disebut cultural universals, yaitu: peralatan dan perlengkapan hidup manusia, mata pencaharian hidup dan sistem-sistem ekonomi, sistem kemasyarakatan, bahasa, kesenian, sistem pengetahuan, dan religi.

Meskipun kebudayaan mempunyai unsurunsur yang bersifat universal, hal tidak berarti bahwa kebudayaan suatu masyarakat akan sama dengan kebudayaan masyarakat lain, contoh yang paling jelas adalah bahasa dan kesenian. Pada umumnya keragaman bentuk kebudayaan antara lain dipengaruhi oleh lokasi di mana masyarakat itu berada dan situasi sosial anggota masyarakat di wilayah masing-masing.

Dari hasil wawancara dengan pelaku kesenian, tokoh masyarakat, dan juga masyarakatumum diketahui bahwa di wilayah ini tercatat seni : calung, jaipongan, degung, pencak silat masih hidup dan berkembang di masyarakat Desa Mekarsari dan di Desa Simpang. Selain kesenian khas yang telah disebutkan tadi, masih dikenal kesenian qasidah dan marawis yang merupakan seni yang sarat dengan budaya Islam. Di sisi lain, terdapat pula kesenian yang kondisinya mengkhawatirkan menjurus ke kepunahan karena myaris tidak lagi dipertontonkan atau ditampilkan dalam kegiatankegiatan seperti : hajatan, acara kenaikan kelas, atau saat perayaan ulang tahun kemerdekaan di bulan Agustus, yaitu kesenian calung, kesenian debus, dan adu domba.

\section{ULASAN KARYA}

Berdasarkan data yang diperoleh dari kuesioner, terlihat adanya hasil yang signifikan bahwa pada umumnya responden di kedua desa menyebutkan kesenian yang masih mereka lihat sehari-hari yaitu jaipongan dan pencak silat. Berikut ini dapat dilihat analisis dari data-data yang diperoleh.

Di Desa Mekarsari pada umumnya terlihat gambaran yang agak berbeda dengan Desa Simpang. Dari 40 responden, selain ibu rumah tangga dan pelajar, penduduk berpenghasilan sebagai buruh atau supir menduduki tempat tertinggi, kemudian berdagang, pegawai 3orang, dan petani 2 orang. Dari segi pendidikan terlihat bahwa pendidikan masyarakat cukup baik yaitu tingkat pendidikan SMA/SMK sebanyak 13, disusul SMP sebanyak 14, dan pendidikan SD cukup tinggi sebanyak 9 orang. Meskipun interview ini dilakukan secara acak, dapat diambil simpul awal bahwa pola kehidupan masyarakat sudah bergeser dari pertanian ke bidang kerja lain.

Responden pada umumnya responden mengenal kesenian khas berupa pencak silat (80\%) dan jaipong $(77,50 \%)$ dan $20 \%$ menyebutkan debus, marawis, dan adu domba. Untuk responden yang berusia di atas 50 tahun masih mengenal kesenian khas yang lain yaitu rampak sekar (5\%) dan gondang (2,5\%). Berdasarkan data tersebut dapat dikatakan bahwa masyarakat hampir tidak mengenal lagi kesenian khas daerahnya, responden mampu menyebutkan jenis-jenis kesenian berdasarkan apa yang mereka lihat sehari-hari karena keseniankesenian tersebut masih sering ditampilkan pada pada hari-hari besar seperti Hari Kemerdekaan setiap tanggal 17 Agustus, perhelatan perkawinan atau khitanan, dan saat kenaikan kelas. Hal ini berindikasi bahwa kesenian khas lambat laun akan punah.

Minat mempelajari kesenian di desa inipun cukup baik, terlihat dari jawaban responden bahwa $62,50 \%$ menyatakan berminat, sementara 37,50\% kurang berminat. Berbeda dengan Desa Simpang yang terlihat bahwa pelaku kesenian belajar seni karena keinginan sendiri, di Desa Mekar sari peran guru cukup dominan untuk mendorong siswanya belajar kesenian khas $(30 \%)$ dan sisanya dorongan dari orang keluarga/ lingkungan sebanyak (10\%).

Mengenai masa depan kesenian khas. 72,50\% responden menyatakan bahwa mereka optimis kesenian khas dapat bertahan di Desa Mekarsari dan $37,50 \%$ menyatakan bahwa kesenian tradisional tidak dapat bertahan mengingat masyarakat jarang sekali melihat penampilan kesenian khas daerah.

Peran aparat desa di desa ini cukup baik, terlihat bahwa $67,50 \%$ responden menyatakan adanya dukungan dari aparat desa dan hanya setengahnya (32,50\%) menyatakan bahwa aparat desa kurang dalam mendorong kesenian tradisional agar tetap berkembang. Pada umumnya masyarakat berpendapat bahwa dalam mempertahankan kesenian khas daerah, kesenian daerah tersebut agar diajarkan di sekolah-sekolah.

Di Desa Simpang pada umumnya responden berpenghasilan sebagai petani, kemudian diikuti sebagai pedagang. Dari 40 responden teredapat 4 orangt apara desa dan 1 orang guru. Dari segi pendidikan terlihat bahwa pendidikan masyarakat cukup baik yaitu tingkat pendidikan SMA/SMK sebanyak 13, disusul SMP sebanyak 12, kemudian SD sebanyak 9 orang.

Responden pada umumnya (50\%) responden mengenal kesenian khas berupa pencak silat dan jaipong dan $15 \%$ menyebutkan dangdut. Berdasarkan data tersebut dapat dikatakan bahwa masyarakat hampir tidak mengenal lagi kesenian khas daerahnya karena jaipong dan dangdut tidak dapat dikategorikan sebagai kesenian tradisional. Hal ini cukup mengkhawatirkan lambat laun kesenian khas akan semakin terpinggirkan bila minat masyarakat lebih menjurus ke kesenian saat ini seperti jaipong dan dangdut. Masyarakat yang berusia di atas 50 tahun menyebutkan jenis kesenian tradisional lain seperti adu domba sebanyak $2,5 \%$ dan 5\% untuk adu domba.

Penyebutan jenis-jenis kesenian tersebut ada korelasi dengan jenis pertunjukan yang masih ditampilkan. Sementara kesenian-kesenian yang di tampilkan pada umumnya memang berupa pencak silat dan jaipong, yang ditampilkan pada hari-hari besar seperti Hari Kemerdekaan setiap tanggal 17 Agustus, perhelatan perkawinan atau khitanan, dan saat kenaikan kelas.

Sesungguhnya di desa ini kesenian khas masih dapat dipelihara karena pada umumnya pelaku kesenian dapat memainkannya karena keinginan sendiri (55\%), sisanya dorongan orang tua atau diajarkan oleh guru dan untuk qasidah/nasyid diajarkan di pesantren. $60 \%$ responden menyatakan bahwa mereka optimis kesenian khas dapat bertahan di Desa Simpang tetapi tokoh kesenian dan pelaku kesenian sendiri (20\%) menyatakan bahwa kesenian tradisional tidak dapat bertahan 
mengingat masyarakatpada kenyataan tidak lagi antusias menyaksikan kesenian khas.

Tampaknya peran aparat desa dalam menyokong terpeliharanya kesenian khas perlu ditingkatkan, $35 \%$ menyatakan adanya dukungan dari aparat desa dan $65 \%$ menyatakan kurangnya aparat desa dalam mendorong kesenian khas agar tetap berkembang karena jarangnya kesenian khas ditampilkan dalam acara-acara. Masyarakat $(47,50 \%)$ pada umumnya menaruh harapan besar bahwa peran aparat desa sangat besar dalam mempertahankan kesenian khas daerah, 20\% menyatakan agar kesenian khas diajarkan di sekolah, dan sisanya menyatakan agar orang tua dan masyarakat turut serta mengambil bagian dalam upaya pelestarian kesenian khas Desa Simpang antara lain dalam acara keramaian tidak hanya menampilkan musik dangdut.

\section{SIMPULAN}

Dari hasil kegiatan PKM-Integratif yang dilaksanakan di Desa Mekarsari dan Desa Simpang, Kecamatan Cikajang, Kabupaten Garut tentang upaya pelestarian kesenian khas di daerah tersebut dapat disimpulkan sebagai berikut:

1. Kesenian Khas yang masih hidup dan berkembang di masyarakat Desa Mekarsari adalah seni calung, jaipongan, degung, pencak silat dan di Desa Simpang seni debus, calung, jaipongan, ibing pencak, qasidah dan marawis yang masih dipentaskan dalam acaraacara tertentu. Dengan demikian, di masing-masing desa di samping adanya jenis kesenian yang sama, masing-masing daerah pun memiliki kesenian yang menonjol di daerahnya. Kesenian yang nyaris punah adalah Adu Domba (sekarang Domba Tangkas) dan kesenian yang sudah punah: kesenian lais, reog, dan debus.
2. Upaya-upaya untuk melestarikan kesenian khas di Kedua Desa Kecamatan Cikajang agar kesenian khas yang dimiliki diajarkan di sekolah-sekolah sebagai kegiatan ekstrakurikuler yang diwajibkan, secara rutin dilakukan penyuluhan dan sosialisasi tentang pentingnya pelestarian kesenian khas daerah sebagai wujud identitas masyarakatnya dan menumbuhkan rasa cinta terhadap warisan budaya leluhur, dan secara berkala dilakukan pagelaran seni dan pasanggir, serta lomba-lomba di bidang kesenian khas sehingga masyarakat antusias mengikutinya.

\section{DAFTAR PUSTAKA}

Danandjaja, James. Folkrore Indonesia: Ilmu Gosip, Dongeng, dan Lain-lain. Jakarta:Grafitipers.

Dienaputra D, Reiza. 2011. Sunda, Sejarah, Budaya, dan Politik. Jatinangor: Sastra Unpad Press.

Sundala 6. 2007. Menyelamatkan Alam Sunda, Pusat Studi Sunda: Bandung

Tim Penyusun Kamus Pusat Bahasa. 2005. Kamus Besar Bahasa Indonesia Edisi Ketiga. Jakarta: Departemen Pendidikan Nasional dan Balai Pustaka.

Ibing Pencak dan Beladiri Pencak dan Latihan http:// silatindonesia.com/2011/02/ibingpencak-danbeladiri-pencak\&latihan

Pemkab Garut http://www.garutkab.go.id/

Pengertian Kebudayaan dan Seni http://etno06. wordpress.com/2010/03/17/pengertiankebudayaan-dan-seni/. 